\title{
Effects of an Injectable Trace Mineral Supplement on First-Service Conception Rate of Dairy Cows
}

\author{
J. A. Vanegas, ${ }^{1}$ J. Reynolds, ${ }^{1}$ and E. R. Atwill ${ }^{1,2}$ \\ ${ }^{1}$ Veterinary Medicine Teaching and Research Center, and \\ ${ }^{2}$ Department of Population Health and Reproduction, \\ University of California-Davis, Tulare 93274
}

\section{ABSTRACT}

A total of 825 dairy cows from a commercial dairy farm in central California were used to evaluate effects of one or 2 doses of an injectable trace mineral supplement containing $20 \mathrm{mg} / \mathrm{mL}$ of zinc, $20 \mathrm{mg} / \mathrm{mL}$ of manganese, $5 \mathrm{mg} / \mathrm{mL}$ of selenium, and $10 \mathrm{mg} / \mathrm{mL}$ of copper on first-service conception rate. Cows were randomly allocated into treatment or control group to either a single dose (experiment 1 ) or a double dose (experiment 2 ) of injected supplement. Allocation was based on days in lactation for experiment 1 and the length of gestation periods for experiment 2 . In experiment 1 , cows 38 to $45 \mathrm{~d}$ in lactation $(\mathrm{n}=190)$ received a single dose of 5 $\mathrm{mL}$ of injected supplement. Similar cows were used as controls $(\mathrm{n}=227)$. In experiment 2 , cows and pregnant heifers received an initial injection of $5 \mathrm{~mL}$ of the mineral supplement from 2 to $3 \mathrm{wk}$ precalving $(\mathrm{n}=186)$. An equal dose was repeated 38 to $45 \mathrm{~d}$ in lactation. A similar group of cows and pregnant heifers served as controls for experiment $2(\mathrm{n}=222)$. Health and reproductive events postcalving were recorded. In experiment 1 , the odds of first-service conception were not significantly different for cows receiving a one-dose regimen of minerals compared with untreated control cows; conception rates were 26.8 and $27.5 \%$ for experiment 1 treatment and control groups, respectively. In experiment 1 , the odds of first-service conception were significantly lower (odds ratio $=0.66$ ) for cows and heifers given the 2-dose regimen of minerals compared with untreated controls; overall conception rates were 21.5 and $31.5 \%$ for experiment 2 treatment and control groups, respectively. In this intensively managed dairy herd, a single dose of injected trace minerals before breeding had no beneficial effects on first-service conception rate. However, dairy cows receiving a dose of trace minerals before calving and another dose before breeding had lower conception at first service.

(Key words: trace mineral, conception rate, injectable)

Received April 14, 2004.

Accepted July 1, 2004.

Corresponding author: Jorge A. Vanegas; e-mail: pajvanegas@ ucdavis.edu.

\section{INTRODUCTION}

In today's dairy production management systems, reproductive efficiency affects the income of any farm by influencing overall milk production, genetic gain, amount of replacement heifers, and wise culling decisions (Ferguson, 1996). Nutrition, management, and genetics play a major role achieving this maximum herd-reproductive performance (Ferguson, 1996). Under the field of nutrition, the effect of trace minerals on reproduction has been always the focus of continuous research. The term micro- or trace mineral refers to those specific elements that are present in small amounts in the diet and are needed in small amounts by the body (Segerson et al., 1977; Corah, 1996). Due to this definition, trace minerals are sometimes ignored or overlooked. Nevertheless, they participate in a wide range of body functions, most of them as components of important enzymatic systems that involve immune, metabolic, and reproductive functions (Hurley et al., 1987; Graham, 1991; Ferguson, 1996; NRC, 2001).

Several reports using oral supplementation of trace minerals on the diet of cattle have shown diverse reproductive effects. Decrease in the number of days to first estrus and increased conception rate have been some of the benefits observed in first calf beef cows (Muehlenbein et al., 2001). However, studies also showed a decrease in reproductive performance in first calf heifers when diets were fed using combinations of trace minerals above the recommended feeding levels (Olson et al., 1999). One of the major disadvantages of the use of dietary mineral supplements is that they may not be absorbed properly due to interactions with other nutrients at the ruminal level (King, 1971; Stake, 1977; Suttle, 1986; Goonerate et al., 1989). Therefore, the alternative use of injectable trace minerals is an area of significant interest. Studies using parenteral supplementation traditionally have involved the use of vitamin $\mathrm{E}$ and selenium around the time of parturition in dairy cows. Responses have been manifested on increases in fertilization and pregnancy rates, reduction on the number of days open, decrease in the incidence of ovarian cyst, and retained placenta (Harrison et al., 1984; Graham, 1991). 
Table 1. Ingredient composition of basal diet and NRC requirements for late-gestation heifers and lategestation dry cows.

\begin{tabular}{|c|c|c|c|c|}
\hline Components (DM basis) & Heifers' diet & $\mathrm{NRC}^{1}$ & Cows' diet & $\mathrm{NRC}^{2}$ \\
\hline Crude protein & 17.4 & 13.5 to 15 & 13.9 & 12 \\
\hline $\mathrm{ADF}$ & 29.6 & 21 & 21.9 & 21 \\
\hline NDF & 40.1 & 33 & 33.4 & 33 \\
\hline $\mathrm{NE}_{\mathrm{L}}(\mathrm{Mcal} / \mathrm{kg})$ & 1.58 & 1.54 to 1.6 & 1.65 & 1.54 to 1.6 \\
\hline Calcium (\%) & 1.07 & 0.4 & 1.11 & 0.6 to 1.5 \\
\hline Phosphorus (\%) & 0.41 & $0.3-0.4$ & 0.35 & 0.3 to 0.4 \\
\hline Magnesium (\%) & 0.27 & 0.35 to 0.40 & 0.37 & 0.35 to 0.4 \\
\hline Potassium (\%) & 2.45 & 0.55 & 1.37 & 1.32 \\
\hline Sodium (\%) & 0.125 & 0.12 & 0.117 & 0.1 \\
\hline Iron $(\mathrm{mg} / \mathrm{kg})$ & 390 & 26 & 423 & 13 \\
\hline Zinc (mg/kg) & 47 & 30 & 67 & 22 \\
\hline Copper (mg/kg) & 20 & 16 & 19 & 13 \\
\hline Selenium (mg/kg) & 0.3 & 0.3 & 0.3 & 0.3 \\
\hline Manganese (mg/kg) & 58 & 22 & 67 & 18 \\
\hline Molybdenum (mg/kg) & 2.1 & 5 to 10 & 1.4 & 5 to 10 \\
\hline
\end{tabular}

${ }^{1} \mathrm{NRC}$ requirements for a transition heifer $270 \mathrm{~d}$ pregnant, weighing $625 \mathrm{~kg}$ with conceptus and consuming $10.6 \mathrm{~kg} \mathrm{DM} / \mathrm{d}$.

${ }^{2} \mathrm{NRC}$ requirements for a transition cow $270 \mathrm{~d}$ pregnant, weighing $751 \mathrm{~kg}$ with conceptus and consuming $13.7 \mathrm{~kg} \mathrm{DM} / \mathrm{d}$.

Recently, a new injectable trace mineral solution, Multimin (Animalia CC., Stellenbosch, Republic of South Africa), containing $20 \mathrm{mg} / \mathrm{mL}$ of zinc, $20 \mathrm{mg} / \mathrm{mL}$ of manganese, $5 \mathrm{mg} / \mathrm{mL}$ of selenium, and $10 \mathrm{mg} / \mathrm{mL}$ of copper has been introduced in the market. The recommended label dose for dairy cows is $5 \mathrm{~mL}$ at $3 \mathrm{wk}$ before calving, with a dose repeated $6 \mathrm{wk}$ after calving and again 5 mo into lactation. Peer-reviewed studies on the effects of Multimin on conception rates have not been reported. However, in a nonpeer-reviewed study by Daugherty et al. (2002), the use of Multimin in combination with parenteral administration of vitamin $\mathrm{E}$ in a group of crossbred beef cows produced nonsignificant differences on days open and overall conception rates.

The objectives of the present study were to evaluate the effects of single or double dose of Multimin on firstservice conception rate of dairy cows using 2 different experimental design conditions.

\section{MATERIALS AND METHODS}

\section{Experimental Animals}

Cows enrolled in the study were from a 2800-cow commercial free-stall dairy in Tulare County, California, with an average 305-d milk production of approximately 11,300 kg per cow. From August 2001 to February 2002 , all confirmed nonlactating pregnant animals (heifers and dry cows) from 263 to $271 \mathrm{~d}$ of gestation and all primiparous and mature cows 38 to $45 \mathrm{~d}$ in lactation were eligible to be included in the study. Lactating cows were housed in free-stall barns and milked 3 times a day. Dry cows were maintained for the entire length of the dry period in dry-lot exercise pens. After calving, all animals were moved to a fresh pen where they spent approximately 10 to $15 \mathrm{~d}$ and then moved to an early lactation pen where they were maintained until the end of the study period. Dry and lactating animals were fed TMR twice per day. Chemical composition of those TMR met or exceeded the National Research Council's requirements for prepartum and early lactation (Tables 1 and 2). Dry matter intake by pen was calculated using a computer feeding management system (Feed Watch, Valley Agricultural Software, Tulare, CA).

\section{Experimental Design}

Nine hundred and thirty-four dairy cows were randomly allocated into 2 experimental groups. In experi-

Table 2. Ingredient composition of basal diet and NRC requirements for lactating dairy cows.

\begin{tabular}{lcc}
\hline $\begin{array}{l}\text { Components } \\
\text { (DM basis) }\end{array}$ & $\begin{array}{l}\text { Lactating } \\
\text { cow diet }\end{array}$ & $\mathrm{NRC}^{1}$ \\
\hline Crude protein & 15.2 & 15.2 to 16 \\
$\mathrm{ADF}$ & 24.5 & 17 to 21 \\
$\mathrm{NDF}$ & 34.3 & 25 to 33 \\
$\mathrm{NE}(\mathrm{Mcal} / \mathrm{kg})$ & 1.62 & 1.54 \\
Calcium $(\%)$ & 0.86 & 0.67 \\
Phosphorus $(\%)$ & 0.51 & 0.36 \\
Magnesium (\%) & 0.31 & 0.2 \\
Potassium $(\%)$ & 1.85 & 1.06 \\
Sodium $(\%)$ & 0.44 & 0.22 \\
Iron $(\mathrm{mg} / \mathrm{kg})$ & 374 & 17 \\
Zinc $(\mathrm{mg} / \mathrm{kg})$ & 64 & 52 \\
Copper $(\mathrm{mg} / \mathrm{kg})$ & 20 & 11 \\
Selenium $(\mathrm{mg} / \mathrm{kg})$ & 0.3 & 0.3 \\
Manganese $(\mathrm{mg} / \mathrm{kg})$ & 47 & 13 \\
Molybdenum $(\mathrm{mg} / \mathrm{kg})$ & 1 & 5 to 10 \\
\hline
\end{tabular}

${ }^{1} \mathrm{NRC}$ requirements for a Holstein cow, $680 \mathrm{~kg}$ BW, 36.2 to $45 \mathrm{~kg}$ of milk production. Dry matter intake of 23.6 to $26.9 \mathrm{~kg}$. 
ment 1, 203 lactating cows, including 93 primiparous cows and 110 multiparous cows 38 to $45 \mathrm{~d}$ in lactation, received a single 5-mL injection of Multimin subcutaneously in the neck (treatment group). A similar group of 246 lactating cows, including 108 primiparous cows and 138 multiparous cows, were used as controls. In experiment 2, 54 late-gestation heifers and 159 late-gestation dry cows ( $\mathrm{n}=213$ nonlactating animals) received an initial injection of $5 \mathrm{~mL}$ of Multimin subcutaneously in the neck from 263 to $271 \mathrm{~d}$ of gestation (treatment group). After calving, 38 to $45 \mathrm{~d}$ in lactation, a second 5 -mL dose of Multimin was administered subcutaneously. A similar group of 272 nonlactating cows, including 103 late-gestation heifers and 169 late-gestation dry cows, served as controls for experiment 2 .

\section{Reproductive Management}

All the cows were enrolled in a timed insemination protocol (Presynch-Ovsynch; Moreira et al., 2001) that included a series of hormonal injections designed to artificially inseminate the cows at a scheduled time without the need for continuous observations of estrus. However, for economic and management purposes, the protocol was modified to include daily morning tailhead paint marking as an aid in detecting estrus. Therefore, all the cows were observed daily for estrus activity and any animal found in estrus was artificially inseminated regardless of their stage in the synchronization protocol. All the breedings followed a voluntary waiting period of 45 to $50 \mathrm{~d}$. At $34 \mathrm{~d}$ postcalving, the animals started the Presynch protocol, which involved the use of 2 doses of $25 \mathrm{mg}$ (i.m.) of $\mathrm{PGF}_{2 \alpha}$ (Lutalyse; Pharmacia Animal Health, Kalamazoo, MI) 14 d apart, with the second injection administered $14 \mathrm{~d}$ before the initiation of the Ovsynch protocol. Ovsynch included the use of $100 \mu \mathrm{g}$ (i.m.) of GnRH (Cystorelin; Merial, Iselin, NJ) followed $7 \mathrm{~d}$ later by a $25-\mathrm{mg}$ i.m. dose of $\mathrm{PGF}_{2 \alpha}$. Cows then received a second i.m. injection of $100 \mu \mathrm{g}$ of $\mathrm{GnRH}$ $48 \mathrm{~h}$ after $\mathrm{PGF}_{2 \alpha}$. If the cow was not detected in estrus by regular observation, a timed insemination was scheduled 16 to $20 \mathrm{~h}$ after the last dose of $\mathrm{GnRH}$. Cows were presented for pregnancy diagnosis 36 to $40 \mathrm{~d}$ postinsemination. For both experimental groups, only information regarding pregnancy outcome for the first breeding were included in the analysis. A cow was considered not pregnant either by rectal palpation or if a subsequent breeding occurred between first insemination and before pregnancy diagnosis.

\section{Data Recording and Evaluation}

In both experiments, date of enrollment, calving dates, health events, culling information, breeding dates, and reproductive status were recorded on the herd's computer record management system (Dairy Comp 305, Valley Ag Software, Tulare, CA) and then entered into a computer spreadsheet (Microsoft Excel, Microsoft Corporation, Redmond, WA). Postparturient health events such as retained placenta and mastitis before the first breeding were recorded and considered in the analysis. Other health disorders such as milk fever or displaced abomasum were taken into consideration in the study design, but due to their rarity, were ignored in the analysis. Any cow that had not expelled the placenta within $24 \mathrm{~h}$ postcalving was defined as having retained fetal membranes. Any cow with abnormalities in the milk or the quarter detected during any of the milkings was classified as a clinical mastitis case.

\section{Statistical Analyses}

Multivariate logistic regression was used to determine if the odds of first-service conception were significantly different for cows given either a 1- or 2-dose regimen of Multimin compared with untreated controls, while simultaneously adjusting for clinical conditions that could affect reproductive efficiency (e.g., retained placenta or mastitis). The experiment 2 control group was set as the referent category for the logistic model; however, the odds ratios and associated $P$ values for comparing experiment 1 treatment with control, and experiment 2 treatment with control can be derived by testing whether the difference between, for example, experiment 1 treatment and experiment 1 control is significantly different from zero, using a 2 -sided test and $\chi^{2}$ distribution. In addition, given that groups of cows were sampled from multiple pens, pen was included as a cluster variable to adjust $P$ values for potential pen-level influences on first-service conception and retention of the fetus (Hardin and Hilbe, 2001). Forward stepping algorithm was used, with $P$ value of 0.10 for inclusion of the term in the model using either a likelihood ratio test or a Wald test. A $\chi^{2}$ goodness-offit test was used to determine the adequacy of the final model. Culling rates for both experimental groups were analyzed using Epicalc 2000 (Gilman and Myatt, 1998; www.myatt.demon.co.uk/) using $2 \times 2$ tables unstratified.

\section{RESULTS AND DISCUSSION}

\section{Experiment 1}

Two hundred twenty-seven untreated controls and 190 Multimin-treated cows completed the single-dose experimental period. The control group comprised 103 (45.4\%) primiparous and $124(54.6 \%)$ mature cows. The treated group consisted of $89(46.8 \%)$ primiparous cows 
Table 3. Final logistic regression model for the effect of 1 (experiment 1) or 2 (experiment 2) 5-mL injections of Multimin $(20 \mathrm{mg} / \mathrm{mL} \mathrm{Zn,} 20 \mathrm{mg} / \mathrm{mL} \mathrm{Mn}, 5 \mathrm{mg} / \mathrm{mL} \mathrm{Se}$, and $10 \mathrm{mg} / \mathrm{mL} \mathrm{Cu}$ ) on the odds of first-service conception in Holstein dairy cattle, adjusted for mastitis, retained placenta, and lactation number. ${ }^{1}$

\begin{tabular}{|c|c|c|c|c|}
\hline Factors & $\begin{array}{l}\text { Regression } \\
\text { coefficient }\end{array}$ & $\begin{array}{l}\text { Odds } \\
\text { ratio }\end{array}$ & $(90 \% \mathrm{CI})^{2}$ & $P$-value ${ }^{3}$ \\
\hline Model Intercept & -0.14 & & $\ldots$ & $\ldots$ \\
\hline $\begin{array}{l}\text { Treatment Group } \\
\text { Experiment 1, control } \\
\text { Experiment 1, treatment } \\
\text { Experiment 2, control } \\
\text { Experiment 2, treatment }\end{array}$ & $\begin{array}{c}-0.19 \\
-0.26 \\
0.0 \\
-0.42\end{array}$ & $\begin{array}{l}0.82 \\
0.77 \\
1.0 \\
0.66\end{array}$ & $\begin{array}{l}(0.57,1.19) \\
(0.47,1.28) \\
\ldots \\
(0.52,0.82)\end{array}$ & $\begin{array}{l}0.39 \\
0.40 \\
\ldots \ldots \\
0.002\end{array}$ \\
\hline $\begin{array}{l}\text { Mastitis before inseminatio } \\
\mathrm{No}^{4} \\
\text { Yes }\end{array}$ & $\begin{array}{c}0.0 \\
-0.66\end{array}$ & $\begin{array}{l}1.0 \\
0.52\end{array}$ & $\overline{(0.34}, 0.77)$ & 0.007 \\
\hline $\begin{array}{l}\text { Retained placenta } \\
\mathrm{No}^{4} \\
\text { Yes }\end{array}$ & $\begin{array}{c}0.0 \\
-0.67\end{array}$ & $\begin{array}{l}1.0 \\
0.52\end{array}$ & $(0.39,0.68)$ & $\ddot{0.001}$ \\
\hline $\begin{array}{l}\text { Lactation number } \\
\text { Lactation number squared }\end{array}$ & $\begin{array}{r}-0.40 \\
0.05\end{array}$ & $\begin{array}{l}0.67 \\
1.05\end{array}$ & $\begin{array}{l}(0.50,0.89) \\
(1.01,1.09)\end{array}$ & $\begin{array}{l}0.023 \\
0.023\end{array}$ \\
\hline
\end{tabular}

${ }^{1}$ Lactation number was modeled as a continuous variable in a quadratic function $\left(\mathrm{x}\right.$ and $\left.\mathrm{x}^{2}\right)$ due to the nonlinear association between lactation number and the likelihood of first-service conception.

${ }^{2} \mathrm{CI}=$ Confidence interval.

${ }^{3}$ Significance determined as a Wald test; $P$-values adjusted for clustering of first-service conception by pen.

${ }^{4}$ Referent category

and $101(53.2 \%)$ mature animals. Thirty-two cows (7\%) were excluded from the analysis, 19 from the control group and 13 from the Multimin-treated group $(P>$ $0.05)$. There was no significant difference by treatment in percentages of cows inseminated based on detected estrus (experiment 1 treatment $=68 \%$, control $=78 \%$ ) or via the timed insemination protocol (experiment 1 treatment $=16.8 \%$, control $=22 \%, P>0.05)$. The odds of first-service conception were not significantly different for mature and primiparous cows given the singledose regimen of Multimin compared with untreatedherd mate controls (odds ratio $=0.94, P=0.63$; Table 3). Overall conception rates were 26.8 and $27.5 \%$ for experiment 1 treatment and control groups, respectively. Lactation number was negatively associated with the odds of first-service conception between lactation 1 and 4 , but then increased for lactations 5 and 6 (Table 3). Recorded health events that might affect conception rate at first breeding were equally distributed among study groups, with no significant differences observed in the numbers of retained placenta (experiment 1 treatment $=9 \%$, control $=8 \%, P=0.7$ ) or mastitis (treatment $=5 \%$, control $=8 \%, P=0.13$ ). However, the odds of first-service conception for cows experiencing retained placenta and mastitis before first breeding were significantly lower compared with cows who did not experience these conditions (odds ratio = $0.52, P<0.01$; Table 3).

There have been no scientific reports on the effects of parenteral administration of combinations of copper, zinc, manganese, and selenium on reproductive performance of dairy cows. Nonetheless, the results of our study are in agreement with an earlier study by Whitaker (1982), where 391 cows from 4 Friesian dairy herds were allocated to receive or not receive a single injection of $400 \mathrm{mg}$ of copper glycinate subcutaneously within a week of calving. Days to first observed heat, service per conception, and first-service conception rate were not significantly different between treated and control groups. However, in that trial, only the effect of supplementation of copper was evaluated without taking into account possible interactions among other minerals, as was the case in the current study. In a similar trial evaluating the use of only one trace mineral parenterally, Arechiga et al. (1998) showed no differences on calving to first insemination or on pregnancy rates at first breeding when lactating cows received $500 \mathrm{mg}$ of vitamin $\mathrm{E}$ as DL- $\alpha$ tocopheryl acetate and $109.5 \mathrm{mg}$ of sodium selenite (i.m.) $30 \mathrm{~d}$ postpartum.

In the current study, cows were fed diets that met or exceeded the NRC recommendations for energy, protein, and minerals (Tables 4 and 5). Previous reports have shown that response to trace mineral supplementation varies according to mineral concentration in the ration. In herds where a specific dietary mineral imbalance or deficiency is present, improvement in reproductive performance manifested as an increase in calving rates (Allan et al., 1993), and decrease in days to first service and days open (Ingraham et al., 1987) have been observed. This is in contrast with studies where diets 
Table 4. Comparison between the calculated dietary intakes, mineral concentration in the ration, and the estimated NRC requirements for different trace minerals for late gestation cows and heifers.

\begin{tabular}{|c|c|c|c|c|c|c|c|c|}
\hline \multirow[b]{2}{*}{ Trace mineral } & \multicolumn{4}{|c|}{ Late gestation heifers } & \multicolumn{4}{|c|}{ Late gestation dry cows } \\
\hline & $\begin{array}{l}\text { Daily } \\
\text { intake }^{1} \\
(\mathrm{mg} / \mathrm{d})\end{array}$ & $\begin{array}{l}\text { Ration }{ }^{2} \\
(\mathrm{mg} / \mathrm{kg})\end{array}$ & $\begin{array}{l}\mathrm{NRC}^{3} \\
(\mathrm{mg} / \mathrm{d})\end{array}$ & $\begin{array}{l}\mathrm{NRC}^{4} \\
(\mathrm{mg} / \mathrm{kg})\end{array}$ & $\begin{array}{l}\text { Daily } \\
\text { intake }^{1} \\
(\mathrm{mg} / \mathrm{d})\end{array}$ & $\begin{array}{l}\text { Ration }^{2} \\
(\mathrm{mg} / \mathrm{kg})\end{array}$ & $\begin{array}{l}\mathrm{NRC}^{3} \\
(\mathrm{mg} / \mathrm{d})\end{array}$ & $\begin{array}{l}\mathrm{NRC}^{4} \\
(\mathrm{mg} / \mathrm{kg})\end{array}$ \\
\hline Copper & 203.6 & 20 & 152 & 15.2 & 266 & 19 & 163.5 & 13.7 \\
\hline Zinc & 478.4 & 47 & 310 & 31 & 938 & 67 & 274 & 22.8 \\
\hline Manganese & 590.4 & 58 & 220 & 22 & 938 & 67 & 213 & 17.8 \\
\hline Selenium & 3 & 0.3 & 3.18 & 0.3 & 4.2 & 0.3 & 4.11 & 0.3 \\
\hline Molybdenum & 21.37 & 2.1 & NA & 5 to $10^{5}$ & 19.6 & 1.4 & NA & 5 to $10^{5}$ \\
\hline
\end{tabular}

${ }^{1}$ Estimated mineral daily intake based on a daily DMI of 10.18 and $14 \mathrm{~kg}$ for heifers and cows, respectively.

${ }^{2}$ Mineral concentration in the ration based on feed analyses.

${ }^{3} \mathrm{NRC}$ estimated dietary mineral requirements $(\mathrm{mg} / \mathrm{d})$.

${ }^{4} \mathrm{NRC}$ recommended dietary mineral concentration $(\mathrm{mg} / \mathrm{kg}$ of $\mathrm{DM})$. Calculations for daily intake and mineral concentration in the ration based on $500-\mathrm{kg}$ heifer at d 250 of gestation and $650-\mathrm{kg}$ cow at $270 \mathrm{~d}$ of gestation.

${ }^{5}$ Maximal tolerable dietary concentration suggested by NRC.

have been formulated to meet or exceed mineral requirements in which supplementation has shown no effects in reproduction (Campbell et al., 1999). Therefore, under specific conditions, administration of trace elements to herds deficient in minerals appears to be beneficial.

Lower conception rates for cows experiencing retained placenta and mastitis before breeding are in agreement with previous studies where significant. Significant negative effects on reproductive performance manifested by an increase in the number of days open (Borsberry and Dobson, 1989), increase in days to first service, and a reduction in first-service conception rate (Fourichon et al., 2000) have been reported for cows that had retained placenta. Also, mastitis early in lactation has been associated with an increase in the days to first service, services per conception, and days open
(Schrick et al., 2001), as well as an increase in the risk for abortion (Risco et al., 1999).

Neither blood nor liver biopsy samples were taken in any of the cows in our study to determine if specific imbalances existed. However, the mineral levels fed in the diets as well as the intakes observed in the cows during the different stages of their productive life makes this unlikely. To better understand the findings of our experiment, further studies are necessary to clarify the effects of administration of parenteral trace minerals when serum and liver trace mineral concentrations are above or below the recommended levels.

\section{Experiment 2}

Two hundred twenty-two controls and 186 Multimintreated cows completed the double-dose experimental

Table 5. Comparison between the calculated dietary intakes, mineral concentration in the ration, and estimated NRC requirements for different trace minerals for lactating dairy cows.

\begin{tabular}{|c|c|c|c|c|c|c|}
\hline \multirow[b]{3}{*}{ Trace mineral } & \multicolumn{2}{|c|}{ Primiparous cows } & \multicolumn{2}{|c|}{ Multiparous cows } & \multirow{2}{*}{\multicolumn{2}{|c|}{ All ages - lactating }} \\
\hline & Daily & & Daily & & & \\
\hline & intake ${ }^{1}$ & $\begin{array}{l}\text { Ration }{ }^{2} \\
(\mathrm{mg} / \mathrm{kg})\end{array}$ & intake $^{1}$ & $\begin{array}{l}\text { Ration }^{2} \\
\text { (mg/kg) }\end{array}$ & $\begin{array}{l}\mathrm{NRC}^{3} \\
(\mathrm{mg} / \mathrm{d})\end{array}$ & $\begin{array}{l}\mathrm{NRC}^{4} \\
(\mathrm{mg} / \mathrm{kg})\end{array}$ \\
\hline Copper & 420 & 20 & 540 & 20 & 313 & 15.7 \\
\hline Zinc & 1344 & 64 & 1728 & 64 & 1267 & 63 \\
\hline Manganese & 987 & 47 & 1269 & 47 & 333 & 16.7 \\
\hline Selenium & 6.3 & 0.3 & 8.1 & 0.3 & 7 to 8 & 0.3 \\
\hline Molybdenum & 21 & 1 & 27 & 1 & $\mathrm{NA}$ & 5 to $10^{5}$ \\
\hline
\end{tabular}

${ }^{1}$ Estimated mineral daily intake based on a daily dry matter intake of 21 and $27 \mathrm{~kg}$ for primiparous cows and older cows, respectively.

${ }^{2}$ Mineral concentrations in the ration based on feed analyses.

${ }^{3} \mathrm{NRC}$ estimated dietary mineral requirements $(\mathrm{mg} / \mathrm{d})$.

${ }^{4}$ Calculations for daily intake and mineral concentrations based on a $650-\mathrm{kg}$ cow, producing $40 \mathrm{~kg}$ of milk/ d. NRC recommended dietary mineral concentration $(\mathrm{mg} / \mathrm{kg}$ of $\mathrm{DM})$.

${ }^{5}$ Maximal tolerable dietary concentration suggested by NRC. 
period. The control group comprised $94(42.3 \%)$ heifers and $128(57.7 \%)$ mature cows. The treament group consisted of $47(25.3 \%)$ heifers and $101(74.7 \%)$ mature animals. Seventy-seven cows (15\%) were excluded from the analysis, 50 from the untreated control and 27 from the Multimin-treated group $(P>0.05)$. No difference in the percentage of cows bred by regular heat detection (experiment 2 treatment $=82 \%$, control $=80 \%$ ) or by the timed insemination protocol (experiment 2 treatment $=$ $18 \%$, control $=20 \%$ ) was observed among study groups $(P>0.05)$. The odds of first-service conception were significantly lower for cows and heifers given the 2-dose regimen of Multimin compared with their untreated controls (odds ratio $=0.66, P=0.002$; Table 3 ). Overall conception rates were 21.5 and $31.5 \%$ for experiment 2 treatment and control groups, respectively. As observed in experiment 1, lactation number was negatively associated with the odds of first-service conception between lactations 1 and 4 , but then increased for lactations 5 and 6 (Table 3).

No significant differences among the incidences of retained placenta (experiment 2 treatment $=8 \%$, control $=7 \%, P=0.76$ ) and clinical mastitis before first breeding (experiment 2 treatment $=8 \%$, control $=5 \%$, $P=0.96$ ) were found between control and the Multimin groups. However, as discussed in experiment 1, the odds of conception were significantly lower for cows experiencing these disease events (Table 3 ).

Previous studies have evaluated the dietary supplementation of trace minerals before calving, but there is limited information regarding their use as parenteral compounds. Our findings, however, contrast the results of an nonpeer-reviewed study by Daugherty et al. (2002), where 67 crossbred beef cows were randomly assigned to receive or not receive an injection of $5 \mathrm{~mL}$ of Multimin plus 6.2 IU/kg BW of vitamin E subcutaneously $30 \mathrm{~d}$ before calving and again $21 \mathrm{~d}$ before the start of the breeding season. No significant differences in conception rates $(P=0.25)$ or for days from calving to conception were found among study groups $(P=0.53)$. Other studies combining the use of selenium and vitamin $\mathrm{E}$ reported a reduction in the incidence of retained fetal membranes (Harrison et al., 1984) and increased conception rates (Arechiga et al., 1998). Moreover, some of those benefits are inconsistent among different experiments (Kappel et al., 1984). In our study, the administration of Multimin 2 to 3 wk before calving had no effect on the incidence of retained fetal membranes.

The decrease in first-service conception rate observed for the cows receiving 2 doses of Multimin in our study agree with earlier reports by Cummins and Harris (1984), where a significant reduction in first-service conception rate was observed in a group of Friesian and Hereford heifers injected twice before the breeding season with an inorganic copper solution. However, only a single trace mineral was evaluated in the latter study without considering multiple mineral interactions. Lower reproductive performances have been reported when cows have been fed mineral combinations of copper, cobalt, manganese, and zinc at higher than the NRC requirement levels for $60 \mathrm{~d}$ before the breeding season (Olson et al., 1999).

No liver or blood samples were taken for trace mineral evaluation that would allow us to determine the presence of potential deficiencies or toxicities that might explain some of our results. However, cows in our study were fed diets that met or exceeded the NRC recommendations for daily mineral concentration in the ration as well as the daily estimates of mineral intakes for every stage of their productive life, making a mineral deficiency unlikely (Tables 4 and 5). The results described in previous reports and in our study suggest that supplementation above the animal's requirements for trace minerals before calving may be of limited value, with potentially negative effects on reproduction.

\section{CONCLUSIONS}

In this intensively managed dairy herd, a 2-dose regimen of Multimin before calving and before breeding resulted in significantly decreased reproductive performance. A single injection of Multimin before breeding had no beneficial effects in first-service conception rate. Although we postulate reasons for the results obtained in the double-dose regimen, a specific physiological answer to why we observed a decrease in first-service conception rate for the cows remains unclear. The rate of retained fetal membranes or mastitis was not different between treatment and control groups. More research is needed to evaluate the effects of trace mineral solutions under different management situations and in dairy herds where possible trace mineral deficiencies in the ration are present.

\section{REFERENCES}

Allan, C. L., R. G. Hemingway, and J. J. Parkins. 1993. Improved reproductive performance in cattle dosed with trace element/vitamin boluses. Vet. Rec. 132:463-464.

Arechiga, C. F., S. Vazquez-Flores, O. Ortiz, J. Hernandez-Ceron, A. Porras, L. R. McDowell, and P. J. Hansen. 1998. Effect of injection of beta-carotene or vitamin $\mathrm{E}$ and selenium on fertility of lactating dairy cows. Theriogenology 50:65-76.

Borsberry, S., and H. Dobson. 1989. Periparturient diseases and their effect on reproductive performance in five dairy herds. Vet. Rec. 124:217-219.

Campbell, M. H., J. K. Miller, and F. N. Schrick. 1999. Effect of additional cobalt, copper, manganese, and zinc on reproduction and milk yield of lactating dairy cows receiving bovine somatotropin. J. Dairy Sci. 82:1019-1025.

Corah, L. 1996. Trace mineral requirements of grazing cattle. Anim. Feed Sci. Technol. 59:61-70. 
Cummins, L. J., and D. J. Harris. 1984. Temporary infertility possibly associated with parenteral copper therapy in cattle. Aust. Vet. J. 61:164-165.

Daugherty, S. R., G. E. Carstens, D. B. Herd, K. S. Barling, and R. D. Randel. 2002. Effects of prenatal and prebreeding trace mineral/ vitamin $\mathrm{E}$ injections on calf health and reproductive performance of beef cows. Beef Cattle Research in Texas Report. Department of Animal Science, Texas A\&M University. Online. Available: http://animalscience.tamu.edu/ansc. Accessed March 15, 2004.

Ferguson, J. D. 1996. Diet, production, and reproduction in dairy cows. Anim. Feed Sci. Technol. 59:173-184.

Fourichon, C., H. Seegers, and X. Malher. 2000. Effect of disease on reproduction in the dairy cow: A meta-analysis. Theriogenology $53: 1729-1759$

Gilman, J., and M. Myatt. 1998. EpiCalc 2000 v1.02. Brixton Books, London, UK.

Gooneratne, S. R., W. T. Buckley, and D. A. Christensen. 1989. Review of copper deficiency and metabolism in ruminants. Can. J. Anim. Sci. 69:819-845.

Graham, T. W. 1991. Trace element deficiencies in cattle. Vet. Clin. North Am. Food Anim. Pract. 7:153-215.

Hardin, J. W., and J. M. Hilbe. 2001. The binomial-logit family. Generalized linear models and extensions. Stata Press, College Station, TX.

Harrison, J. H., D. D. Hancock, and H. R. Conrad. 1984. Vitamin E and selenium for reproduction of the dairy cow. J. Dairy Sci. 67:123-132.

Hurley, W. L., and R. M. Doane. 1989. Recent developments in the roles of vitamins and minerals in reproduction. J. Dairy Sci. 72:784-804.

Ingraham, R. H., L. C. Kappel, E. B. Morgan, and A. Srikandakumar. 1987. Correction of subnormal fertility with copper and magnesium supplementation. J. Dairy Sci. 70:167-180.

Kappel, L. C., R. H. Ingraham, E. B. Morgan, J. M. Dixon, L. Zeringue, D. Wilson, and D. K. Babcock. 1984. Selenium concentrations in feeds and effects of treating pregnant Holstein cows with selenium and vitamin $\mathrm{E}$ on blood selenium values and reproductive performance. Am. J. Vet. Res. 45:691-694.
King, J. O. 1971. Nutrition and fertility in dairy cows. Vet. Rec. 89:320-324.

Moreira, F., C. Orlandi, C. A. Risco, R. Mattos, F. Lopes, and W. W. Thatcher. 2001. Effects of presynchronization and bovine somatotropin on pregnancy rates to a timed artificial insemination protocol in lactating dairy cows. J. Dairy Sci. 84:1646-1659.

Muehlenbein, E. L., D. R. Brink, G. H. Deutscher, M. P. Carlson, and A. B. Johnson. 2001. Effects of inorganic and organic copper supplemented to first-calf cows on cow reproduction and calf health and performance. J. Anim. Sci. 79:1650-1659.

National Research Council. 2001. Nutrient Requirements of Dairy Cattle. 7th rev. ed. Natl. Acad. Sci., Washington, DC.

Olson, P. A., D. R. Brink, D. T. Hickok, M. P. Carlson, N. R. Schneider, G. H. Deutscher, D. C. Adams, D. J. Colburn, and A. B. Johnson. 1999. Effects of supplementation of organic and inorganic combinations of copper, cobalt, manganese, and zinc above nutrient requirement levels on postpartum two-year-old cows. J. Anim. Sci. 77:522-532.

Risco, C. A., G. A. Donovan, and J. Hernandez. 1999. Clinical mastitis associated with abortion in dairy cows. J. Dairy Sci. 82:16841689.

Schrick, F. N., M. E. Hockett, A. M. Saxton, M. J. Lewis, H. H. Dowlen, and S. P. Oliver. 2001. Influence of subclinical mastitis during early lactation on reproductive parameters. J. Dairy Sci. 84:1407-1412.

Segerson, E. C., Jr., F. A. Murray, A. L. Moxon, D. R. Redman, and H. R. Conrad. 1977. Selenium/vitamin E: Role in fertilization of bovine ova. J. Dairy Sci. 60:1001-1005.

Stake, P. E. 1977. Trace element absorption factors in animals. Pages 137-150 in Proc. 38th Minnesota Nutrition Conference. Minneapolis, MN. Minnesota Agricultural Extension Service, Minneapolis, $\mathrm{MN}$.

Suttle, N. F. 1986. Problems in the diagnosis and anticipation of trace element deficiencies in grazing livestock. Vet. Rec. 119(7):148152

Whitaker, D. A. 1982. A field trial to assess the effect of copper glycinate injections on fertility in dairy cows. Br. Vet. J. 138:40-44. 